\title{
Spray nozzles and curtain of chains in fungicide application to control Asian soybean rust
}

\section{Pontas de pulverização e cortina de correntes na aplicação de fungicidas para 0 controle da ferrugem Asiática da soja}

\author{
Henrique Facco LUFIEGO ${ }^{1}$; Walter BOLLER ${ }^{2}$; Marcelo Silveira de FARIAS ${ }^{3}$; José Fernando SCHLOSSER ${ }^{4}$; \\ Gilvan Moisés BERTOLLO ${ }^{5}$ \\ ${ }^{1}$ Engenheiro Agrônomo. Egresso da Universidade de Passo Fundo. henriquefaccolufiego@gmail.com \\ ${ }^{2}$ Doutor em Agronomia. Universidade Federal de Santa Maria. boller@upf.br \\ ${ }^{3}$ Autor para correspondência. Doutor em Engenharia Agrícola. Universidade Federal de Santa Maria, Campus de Frederico \\ Westphalen, Departamento de Ciências Agronômicas e Ambientais. Linha 7 de Setembro, s/n, BR 386 km 40, CEP: $98400-$ \\ 000, Frederico Westphalen, RS. silveira_farias@hotmail.com \\ ${ }_{5}^{4}$ Doutor em Engenharia Agrícola. Universidade Federal de Santa Maria. josefernandoschlosser@gmail.com \\ 5 Doutor em Engenharia Agrícola. Universidade Tecnológica Federal do Paraná, Campus Santa Helena. \\ gilvanbertollo@yahoo.com.br
}

Recebido em: 03-09-2021; Aceito em: 29-10-2021

\begin{abstract}
The proper choice of spray nozzles and spray boom configuration is of paramount importance for fungicidal effectiveness, promoting better foliar coverage, especially in the lower canopy of the crop. In this sense, the present study evaluates the influence of fungicides applied with different spray nozzles, with and without curtain of chains, on Asian rust control and on the yield of soybean cultivar BMX Ativa RR. The experimental design was a randomized block, with four spray nozzles (Albuz ${ }^{\circledR}$ ATR 1.0; Albuz ${ }^{\circledR}$ ATR 0.5; Magnojet ${ }^{\Theta}$ ADT 11002; and Magnojet ${ }^{\Theta} \mathrm{CH} 100$ ) and two spray boom configurations (with curtain of chains; and without curtain of chains). The experiment had four replicates and a control without fungicide application. The variables under study were the severity and control of Asian soybean rust, thousand grain weight, and soybean yield. The results indicate that using the curtain of chains in fungicide applications is a technically viable alternative to increase soybean yield. When used along with empty conical jet and triple flat jet nozzles, this technology is highly efficient in controlling Asian soybean rust.
\end{abstract}

Additional keywords: application technology; droplet deposition; Phakopsora pachyrhizi.

\section{Resumo}

A escolha adequada de pontas de pulverização e de configuração da barra do pulverizador é de suma importância na eficácia de fungicidas, promovendo melhor cobertura foliar do mesmo, especialmente no dossel inferior da cultura. Neste sentido, este trabalho teve como objetivo avaliar a influência de fungicidas aplicados com diferentes pontas de pulverização com e sem cortina de correntes na barra, no controle da ferrugem asiática e na produtividade da cultura da soja, cultivar BMX Ativa RR. O delineamento experimental utilizado foi de blocos casualizados, com quatro pontas de pulverização (Albuz ${ }^{\circledR}$ ATR 1.0; Albuz $^{\circledR}$ ATR 0.5; Magnojet ${ }^{\Theta}$ ADT 11002; e Magnojet ${ }^{\Theta} \mathrm{CH} 100$ ) e duas configurações de barra de pulverização (com cortina de correntes; e sem cortina de correntes), com quatro repetições e uma testemunha, sem aplicação de fungicidas. As variáveis analisadas foram a severidade e o controle da ferrugem asiática da soja, massa de mil grãos e produtividade. Os resultados indicam que a adoção da cortina de correntes nas aplicações de fungicidas é uma alternativa tecnicamente viável para aumentar a produtividade da cultura da soja, visto que essa tecnologia, aliada à utilização de pontas de jato cônico vazio e de jato plano triplo, proporcionam maior eficiência de controle da ferrugem asiática da soja.

Palavras-chave adicionais: deposição de gotas; Phakopsora pachyrhizi; tecnologia de aplicação.

\section{Introduction}

Soybean [Glycine max (L.) Merrill] is of great economic importance to Brazil, being the main crop of Brazilian agribusiness. In the 2020/21 harvest, 38.5 million hectares were cultivated with this crop in the country, reaching a production of 135.5 million tons (CONAB, 2021). Currently, Brazil is the world's largest producer of soybean. This scenario is due to the development and structuring of a solid international market, which correlates with the trade of products of the soybean agroindustrial complex and with the consolidation of this oleaginous plant as an important source of vegetable protein. The crop has a special importance in meeting the growing demands of the sectors linked to the production of products of animal origin, as well as in the generation and supply of 
technologies, which enabled its expansion (Hirakuri \& Lazzarotto, 2014).

Population expansion, increased longevity, and changes in consumption patterns will increase the demand for food, energy, and water (Moretti, 2019). In this scenario, the use of new techniques as a way to guarantee the yield of this crop becomes of fundamental importance for the world population. The evolution of pesticide application technology correlates directly with the growing economic importance of soybean. However, according to Stefanello (2020), droplet penetration in the crop canopy is an important factor for the chemical control of diseases, especially diseases that start in the lower region of the plant.

According to Antuniassi \& Boller (2011), very fine droplets (smaller than $100 \mu \mathrm{m}$ ) result in better coverage and penetration, but are more susceptible to drift loss. On the other hand, large droplets (larger than $400 \mu \mathrm{m})$ have low penetration capacity in the plant canopy, as in the case of soybean crop, in the reproductive phase. One of the ways to partially circumvent this problem is by adopting a process to optimize the choice of droplet size as a function of atmospheric conditions, using the most suitable droplet for each temperature and relative humidity situation (Antuniassi \& Boller, 2019).

Soybean rust, caused by the fungus Phakopsora pachyrhizi Sydow \& Sydow, is present in all soybean-producing countries. The use of fungicides is one of the main strategies in disease management. However, the activity requires an operational team and equipment, which increases costs (Hoffmann, 2016). For the control of Asian soybean rust, the fungicide must reach the interior of the canopy, mainly the bottom of the plant, and provide uniform coverage and distribution throughout the plant.

Regarding the type of nozzles, when evaluating the volume of water deposition of three different models of spray nozzles (AXI 11002, AXI TWIN 12002, and J3D 10002), Souza et al. (2019) observed a difference in the depositions. In turn, when evaluating 13 different types of spray nozzles for the control of Asian soybean rust, Cunha, Juliatti, and Reis (2014) concluded that nozzles with medium droplets showed better results for deposition of the applied fungicide spray.

Technological innovations are necessary to improve droplet deposition on the target, optimizing the use of chemical products and reducing production costs, which would be of great importance in the control of Asian soybean rust (Christovam et al., 2010). In this sense, sprayers now have a device next to the spray boom that allows for air assistance. This technology reduces drift, increases droplet penetration in the crop canopy, and improves spray distribution (Bauer \& Raetano, 2000). Another technology is the curtain of chains, which consists of a series of steel chains hanging from metal tubes. These chains sweep the plant canopy through the movement of the spray boom, bending the plants in front of the nozzles and thus exposing the lower strata of the crop for the deposition of droplets of phytosanitary products (Moura et al., 2017).

Therefore, the present study evaluates the influence of different spray nozzles, with and without curtain of chains on the boom, on Asian soybean rust control and soybean yield.

\section{Material and methods}

The experiment was conducted in the Experimental Field of the Faculty of Agronomy and Veterinary Medicine (FAMV) of the University of Passo Fundo (UPF), in the Middle Plateau region of Rio Grande do Sul State, Brazil, in the agricultural year 2018/2019. The experimental soil is a clayey Humic Red Latosol (Santos et al., 2018). According to the Köppen-Geiger classification, the climate is type Cfa (humid subtropical), with hot summers and undefined dry season.

Cover crops prior to the installation of the experiment were black oat (Avena strigosa Schreb) and ryegrass (Lolium multiflorum Lam), in an intercropping system. The soybean crop was planted in direct tillage, after desiccation of the winter crops, with the herbicides glyphosate $\left(2.0 \mathrm{~L} \mathrm{ha}^{-1}\right)$ and clethodim $\left(0.5 \mathrm{~L}^{-1}\right)$, both manufactured and registered by Norto ${ }^{\circledR}$ company. Soybean cultivar BMX Ativa RR, with determinate growth habit, was sown in the third tenth of November, at a fixed rate of 300,000 seeds ha ${ }^{-1}$ and spacing of 0.50 meters between rows.

The soybean crop was fertilized with $250 \mathrm{~kg}$ of the formulate (N-P-K 2-20-20) per hectare, in the sowing row. Postemergence weed control was carried out by applying the herbicide glyphosate (Roundup ${ }^{\circledR}$ $\left.2.0 \mathrm{~L} \mathrm{ha}^{-1}\right)$. For pest control, the following insecticides were applied: chlorantraniliprole $\left(\right.$ Premio $^{\circledR}-50 \mathrm{mLha}^{-1}$ ); thiamethoxan + lambda cyhalothrin (Engeo Pleno ${ }^{\circledR}$ $200 \mathrm{~mL} \mathrm{ha}^{-1}$ ), used together with the first and second application of fungicides to control caterpillars; and imidacloprid + bifenthrin $\left(\right.$ Galil ${ }^{\circledR}-400 \mathrm{~mL} \mathrm{ha}^{-1}$ ), used together with the third and fourth application of fungicides to control caterpillars and stink bugs.

In the control plots only insecticides were applied, on the same dates as the fungicide application. The applications of pesticides, including fungicides to control Asian rust (Table 1), were carried out with Jacto boom sprayer (model Falcon Vortex), mounted on the three-point hydraulic system of an agricultural tractor, and equipped with a curtain of chains on the spray boom, as described by Moura et al. (2017). 
Table 1 - Detailed description (date, crop stage, products, and doses used) of the four fungicide applications, carried out at intervals of 18 days.

\begin{tabular}{|c|c|c|c|c|c|}
\hline \multirow{2}{*}{ Date } & \multirow{2}{*}{ Crop stage } & \multicolumn{4}{|c|}{ Product used } \\
\hline & & Fungicide & Dose & Oil & Dose \\
\hline $01 / 10 / 2019$ & $\mathrm{R} 1$ & Fox $^{(8) 1}+$ Unizeb Gold $^{(B 2}$ & $0.4 \mathrm{~L} \mathrm{ha}^{-1}+2.0 \mathrm{~kg} \mathrm{ha}^{-1}$ & Aureo ${ }^{(85}$ & $250 \mathrm{ml} \mathrm{ha}^{-1}$ \\
\hline $01 / 28 / 2019$ & R3 & Fox $^{(B)}+$ Unizeb Gold ${ }^{(B)}$ & $0.4 \mathrm{~L} \mathrm{ha}^{-1}+2.0 \mathrm{~kg} \mathrm{ha}^{-1}$ & Aureo $^{(B)}$ & $250 \mathrm{ml} \mathrm{ha}^{-1}$ \\
\hline 02/16/2019 & $\mathrm{R} 4$ & Cronnos $^{(\circledast 3}$ & $2.5 \mathrm{~L} \mathrm{ha}^{-1}$ & Nimbus $^{(16}$ & $500 \mathrm{ml} \mathrm{ha}^{-1}$ \\
\hline 03/06/2019 & R5.4 & Versatilis $^{(\circledR 4}+$ Unizeb Gold $^{(\Theta)}$ & $0.3 \mathrm{~L} \mathrm{ha}^{-1}+2.0 \mathrm{~kg} \mathrm{ha}^{-1}$ & Assist $^{(B) 6}$ & $500 \mathrm{ml} \mathrm{ha}^{-1}$ \\
\hline
\end{tabular}

${ }^{1}$ Trifloxystrobin + prothioconazole. ${ }^{2}$ Mancozeb. ${ }^{3}$ Picoxystrobin + tebuconazole + mancozeb. ${ }^{4}$ Fenpropimorph. ${ }^{5}$ Vegetable oil. ${ }^{6}$ Mineral oil.

The curtain consists of a series of steel chains spaced $0.15 \mathrm{~m}$ apart, hanging from metal tubes. The tubes were attached to the spray boom, $0.06 \mathrm{~m}$ in front of the spray nozzles, forming an angle of $30^{\circ}$ perpendicular to the ground. Since the width of the experimental units was $3.15 \mathrm{~m}$, applications with the curtain of chains were made using a $3.0 \mathrm{~m}$ spray boom with 20 chains. In applications performed without the curtain of chains, the spray boom was the same as a conventional sprayer.

Environmental conditions during fungicide applications were monitored with the digital thermohygro-anemometer Kestrel ${ }^{\circledR}$ (model 3000 ). In the early morning (8:30h - 10:00h), these conditions were as follows: temperature of $21 \pm 2{ }^{\circ} \mathrm{C}$; relative air humidity of $76 \pm 5 \%$; and wind speed between 2.5 and $4.8 \mathrm{~km} \mathrm{~h}$ 1 , in the west direction. In the late morning $(10: 00 \mathrm{~h}$ $11: 30 \mathrm{~h}$ ), the conditions were: temperature of $27.5 \pm 2$ ${ }^{\circ} \mathrm{C}$; relative air humidity of $57 \pm 2 \%$; and wind speed between 4.7 and $7.8 \mathrm{~km} \mathrm{~h}^{-1}$, also in the west direction.

The experiment was conducted in a randomized block design, testing four spray nozzles (Albuz $^{\circledR}$ ATR 1.0; Albuz ${ }^{\circledR}$ ATR 0.5; Magnojet $^{\circledR}$ ADT 11002; and Magnojet ${ }^{\Theta} \mathrm{CH} 100$ ) and two spray boom configurations (with curtain of chains; and without curtain of chains), having a control without application of fungicides (Table 2). The plots were $10 \mathrm{~m}$ long and 3 $\mathrm{m}$ wide, each comprising six sowing rows spaced 0.5 $\mathrm{m}$ apart. The boom section was mounted on the right side of the sprayer.

Table 2 - Volume of water, spacing between spray nozzles, travel speed, jet angle and type, and droplet size, with and without the use of curtain of chains, for different spray nozzles.

\begin{tabular}{|c|c|c|c|c|c|c|c|}
\hline \multicolumn{2}{|c|}{ Spraying } & \multirow{2}{*}{$\begin{array}{c}\text { Volume of } \\
\text { water }\left(\mathrm{L} \mathrm{ha}{ }^{-1}\right)\end{array}$} & \multirow{2}{*}{$\begin{array}{l}\text { Spacing between } \\
\text { nozzles }(\mathrm{m})\end{array}$} & \multirow{2}{*}{$\begin{array}{l}\text { Travel speed } \\
\quad\left(\mathrm{km} \mathrm{h}^{-1}\right)\end{array}$} & \multirow{2}{*}{$\begin{array}{l}\text { Jet angle } \\
\text { (degrees) }\end{array}$} & \multirow[b]{2}{*}{ Jet type } & \multirow{2}{*}{$\begin{array}{c}\text { Droplets } \\
\text { size }^{*}\end{array}$} \\
\hline $\begin{array}{c}\text { Boom } \\
\text { configuration }\end{array}$ & Spray nozzle & & & & & & \\
\hline \multirow{4}{*}{$\begin{array}{l}\text { With the } \\
\text { curtain of } \\
\text { chains }\end{array}$} & ATR 1.0 & $75^{1}$ & 0.50 & 5.12 & 80 & Empty conical & Fine \\
\hline & ATR 0.5 & 75 & 0.25 & 7.68 & 80 & Empty conical & Fine \\
\hline & ADT 11002 & $150^{2}$ & 0.50 & 6.00 & 40 entre jatos & Triple flat & Medium \\
\hline & $\mathrm{CH} 100$ & 150 & 0.50 & 6.00 & 100 & Full conical & Medium \\
\hline \multirow{4}{*}{$\begin{array}{l}\text { Without the } \\
\text { curtain of } \\
\text { chains }\end{array}$} & ATR 1.0 & 75 & 0.50 & 5.12 & 80 & Empty conical & Fine \\
\hline & ATR 0.5 & 75 & 0.25 & 7.68 & 80 & Empty conical & Fine \\
\hline & ADT 11002 & 150 & 0.50 & 6.00 & 40 entre jatos & Triple flat & Medium \\
\hline & $\mathrm{CH} 100$ & 150 & 0.50 & 6.00 & 100 & Full conical & Medium \\
\hline
\end{tabular}

${ }^{1}$ Treatments with volume of water of $75 \mathrm{~L} \mathrm{ha}^{-1}$ and fine droplets were applied in the early morning, between 08:30 $\mathrm{h}$ and 10:00 h. ${ }^{2}$ Treatments with volume of water of $150 \mathrm{~L} \mathrm{ha}^{-1}$ and medium droplets were applied in the late morning, between 10:00 $\mathrm{h}$ and 11:30 h. *Droplets size according to the ASABE S572.1 standard (ASABE, 2009).

Application volumes, spacings, angles, and travel speeds were determined to maintain the pattern of fine droplets in the early morning, and medium droplets in the late morning. In the latter period, atmospheric conditions such as temperature, relative air humidity, and wind speed tend to oscillate, making it necessary to use larger drops to avoid drift and evaporation.

The severity of Asian soybean rust was visually assessed 14 days after the last fungicide application, on 03.20.2019, by collecting five plants from the central rows of each plot. For this, the diagrammatic scale proposed by Godoy et al. (2006) was used. From the severity readings, the percentage of Asian soybean rust control was calculated as a function of the control treatment. Harvest was carried out in a mechanized way in the three central cultivation rows within each experimental unit $\left(15 \mathrm{~m}^{2}\right)$. Grain yield values were corrected for $13 \%$ moisture. Then, thousand grain weight and grain yield were determined.

The response variables (severity, Asian soybean rust control, thousand grain weight, and yield) were subjected to analysis of variance $(p \leq 0.05)$. In case of significance, the means of qualitative data were analyzed by the Tukey test $(p \leq 0.05)$ using the SISVAR software version 5.3 (Ferreira, 2014). 


\section{Results and discussion}

Table 3 shows the summary of the analysis of variance (ANOVA) of the severity and control of Asian soybean rust for the different spray nozzles and boom configurations. The results show that there was no interaction between the factors. The analysis of simple effects shows a difference for the factors in the parameters under study. The low values of the coefficients of variation (CV), which represent the standard deviation expressed as a percentage of the mean, reveal the precision of the experiment.

Table 3 - Summary of the ANOVA for the parameters severity (\%) and control (\%) of Asian soybean rust, and thousand grain weight $(\mathrm{g})$ and yield $\left(\mathrm{kg} \mathrm{ha}^{-1}\right)$ of soybean cultivar BMX Ativa RR.

\begin{tabular}{lccccc}
\hline \multirow{2}{*}{ Sources of variation } & $\begin{array}{c}\text { Degrees of } \\
\text { freedom }\end{array}$ & Severity & Control & $\begin{array}{c}\text { Thousand grain } \\
\text { weight }\end{array}$ & Yield \\
\cline { 3 - 6 } & & $442.20^{*}$ & $1572.60^{*}$ & 7.03 & $513357^{*}$ \\
Chain $(\mathrm{C})$ & 1 & $34.41^{*}$ & $122.40^{*}$ & 17.45 & 29008 \\
Nozzle (N) & 3 & 2.68 & 9.54 & 15.36 & 170551 \\
C x N & 3 & 0.69 & 2.46 & $84.11^{*}$ & $229550^{*}$ \\
Block & 3 & 59.86 & 10.14 & 23.99 & 61050 \\
Residue & 21 & 11.44 & 4.41 & 2.82 & 4.64 \\
\hline CV $(\%)$ & & & & &
\end{tabular}

${ }^{*}$ Differ statistically by Tukey test $(\rho \leq 0.05)$.

Thousand grain weight was not influenced by the curtain of chains or spray nozzles. However, yield was significantly higher with the use of the curtain of chains on the spray boom. Nozzles ATR 1.0; ATR 0.5, and ADT 11002 further reduced the severity and increased the control of Asian rust in relation to nozzle $\mathrm{CH} 100$ (Table 4). The lower efficiency of the nozzle $\mathrm{CH} 100$ may be due to the fact that it produces a full conical jet, resulting in larger and uneven droplets in relation to the those of other nozzles.

Table 4 - Average results for the parameters severity (\%) and control (\%) of Asian soybean rust, and thousand grain weight $(\mathrm{g})$ and yield $\left(\mathrm{kg} \mathrm{ha}^{-1}\right)$ of soybean cultivar BMX Ativa RR.

\begin{tabular}{|c|c|c|c|c|}
\hline & Severity (\%) & Control (\%) & $\begin{array}{c}\text { Thousand grain } \\
\text { weight }(\mathrm{g})\end{array}$ & Yield $\left(\mathrm{kg} \mathrm{ha}^{-1}\right)$ \\
\hline \multicolumn{5}{|c|}{ Spray nozzle } \\
\hline ATR 1.0 & $13.92^{\mathrm{b}^{*}}$ & $73.76^{\mathrm{a}}$ & $175.60^{\text {NS }}$ & $5270.00^{N S}$ \\
\hline ATR 0.5 & $14.38^{\mathrm{b}}$ & $72.89^{a}$ & 172.50 & 5359.00 \\
\hline ADT 11002 & $13.00^{\mathrm{b}}$ & $75.49^{\mathrm{a}}$ & 173.80 & 5400.00 \\
\hline $\mathrm{CH} 100$ & $17.75^{\mathrm{a}}$ & $66.53^{\mathrm{b}}$ & 172.50 & 5292.00 \\
\hline \multicolumn{5}{|c|}{ Spray boom configuration } \\
\hline $\begin{array}{l}\text { Without the curtain } \\
\text { of chains }\end{array}$ & $18.48^{\underline{a}}$ & $65.16^{b}$ & $174.10^{\mathrm{NS}}$ & $5204.00^{b}$ \\
\hline $\begin{array}{l}\text { With the curtain of } \\
\text { chains }\end{array}$ & $11.04^{b}$ & $79.18^{a}$ & 173.10 & $5457.00^{\mathrm{a}}$ \\
\hline
\end{tabular}

${ }^{*}$ Means followed by the same letter in the column do not differ by the Tukey test $(p \leq 0.05)$. NS - Nonsignificant difference by the $F$ test at $5 \%$ probability.

Air-assisted sprayers near the spray boom can minimize drift losses through spray nozzles that produce fine droplets (Bauer \& Raetano, 2000). In this way, air assistance increases the use efficiency of fine droplets by reducing drift and increasing deposition on the target, in addition to allowing greater droplet penetration in more leafy crops, reducing soil losses (Bauer \& Raetano, 2000).

Spray nozzles that produce medium droplets improve fungicide deposition and Asian soybean rust control in relation to nozzles that produce fine droplets (Cunha et al., 2014; Durão \& Boller, 2017).
Furthermore, the use of the curtain of chains on the spray boom increased Asian soybean rust control and soybean yield. These results corroborate those of Moura et al. (2017), who also used the cultivar BMX Ativa RR, with a determinate growth habit.

The percentage of Asian rust control was higher with the use of the curtain of chains on the spray boom (Table 4). There is a lack of research on this mechanism; however, results for the air curtain include faster droplet deposition, improved vertical distribution of the spray (Oliveira et al., 2016), and lower risk of drift (Bauer \& Raetano, 2000; Prado et al., 2010). Thus, the 
curtain of chains can be another tool to help control Asian rust, as demonstrated in the present study.

In another study with air assistance on the spray boom, Christovam et al. (2010) obtained an increase of $4.86 \%$ in grain yield. The authors state that the pressurized air moves the leaves of plants, exposing their lower surfaces to a greater amount of product than in conventional application. Moreover, the transverse movement of air through the vegetative canopy increases the probability of deposition at the base of the plants.

There is also an interaction between adjuvants and other factors related to application technology, in particular droplet size and application volume, which in turn correlate with the type of spray nozzle and working pressure (Mota \& Antuniassi, 2013). In addition to these technologies, the curtain of chains proved to be an effective tool to help control Asian rust in soybean crops.

\section{Conclusions}

The use of the curtain of chains in fungicide applications is a technically viable alternative to increase soybean yield. When used along with empty conical jet and triple flat jet nozzles, this technology reduces the severity and improves the control of Asian soybean rust.

\section{References}

Antuniassi UR, Boller W (2011) Tecnologia de aplicação de fungicidas. In: Antuniassi UR, Boller W Tecnologia de aplicação para culturas anuais. Passo Fundo: Aldeia Norte. p.221-229.

Antuniassi UR, Boller W (2019). Tecnologia de aplicação para fungicidas. In: ANTUNIASSI, U. R.; BOLLER, W. Tecnologia de Aplicação para Culturas Anuais. 2 ed. Passo Fundo: Aldeia Norte, 2019. p. 283-302.

ASABE (2009) American Society of Agricultural and Biological Engineers. ASABE S572: Spray Nozzle Classification by Droplet Spectra, St. Joseph.

Bauer FC, Raetano CG (2000) Assistência de ar na deposição e perdas de produtos fitossanitários em pulverizações na cultura da soja. Scientia Agrícola 57(2):271-276.

Christovam RS, Raetano CG, Dal Pogetto MHFA, Prado EP, Aguiar Júnior HO, Gimenes MJ, Serra ME (2010) Effect of nozzle angle and air-jet parameters in air-assisted sprayer on biological effect of soybean Asian rust chemical protection. Journal of Plant Protection Research 50(3):347-353.

CONAB (2021) Companhia Nacional de Abastecimento. Acompanhamento da Safra Brasileira. 7(6)1-89.
Cunha JPAR, Juliatti FC, Reis EF (2014) Tecnologia de aplicação de fungicida no controle da ferrugem asiática da soja: resultados de oito anos de estudos em Minas Gerais e Goiás. Bioscience Journal 30(4):950-957.

Cunha JPAR, Juliatti FC, Reis EF (2014). Tecnologia de aplicação de fungicidas no controle da ferrugem asiática da soja: resultados de oito anos de estudos em Minas Gerais e Goiás. Bioscience Journal, Uberlândia, 30 (4): 950-957.

Durão CF, Boller W (2017) Spray nozzles performance in fungicide applications for Asian Soybean Rust control. Engenharia Agrícola 37(4):709-716.

Ferreira DF (2014) Sisvar: a Guide for its Bootstrap procedures in multiple comparisons. Ciência e Agrotecnologia 38(2):109-112.

Godoy CV, Koga LJ, Canteri MG (2006) Diagrammatic scale for assessment of soybean rust severity. Fitopatologia Brasileira 31(1):63-68.

Hirakuri MH, Lazzaroto JJ (2014) O agronegócio da soja nos contextos mundial e brasileiro. Londrina: Embrapa Soja. 37p.

Hoffmann LL (2016). Controle da ferrugem asiática da soja e suas relações com a planta, manejo e tecnologia de aplicação. Tese. (Doutorado em Fitopatologia) - Faculdade de Agronomia e Medicina Veterinária da UPF, Universidade de Passo Fundo, Passo Fundo, RS, 2016.

Moretti CL (2019). Alimentos para o mundo. Agropecuária - Embrapa, 2019. Disponível em: < https://www.embrapa.br/busca-de-noticias//noticia/47327924/artigo---alimentos-para-o-mundo>. Acesso em 08 out. 2021.

Mota AAB, Antuniassi UR (2013) Influence of adjuvants on the droplet spectrum of an air induction nozzle. Energia na Agricultura 28(1):1-5.

Moura B, Deuner CC, Visintin G, Boller W (2017) Use of a canopy opener in fungicide applications to improve Asian Soybean Rust control. Transactions of the ASABE 60(6):1819-1825.

Prado EP, Raetano CG, Aguiar Júnior HO, Dal Pogetto MHFA, Christovam RS, Gimenes MJ, Araújo D (2010) Velocidade do ar em barra de pulverização na deposição da calda fungicida, severidade da ferrugem asiática e produtividade da soja. Summa Phytopathologica 36(1):45-50.

Oliveira GM, Canteri MG, Saab OJGA (2016) Metaanalysis of scientific studies related to pesticide 
application techniques-air assistance and adjuvante addition. Ciência Rural 46(12):2122-2128.

Santos HG, Jacomine PKT, Anjos LHC, Oliveira VA, Lumbreras JF, Coelho MR, Almeida JA, Araújo Filho JC, Oliveira JB, Cunha TJF (2018) Sistema Brasileiro de Classificação de Solos. 5.ed. Rio de Janeiro: Embrapa Solos. 353p.
Souza ALC, Sousa CAF, Silva RF, Leite SM (2019). Comparativo de deposição de gotas em diferentes modelos de ponta tipo leque. Revista Unimar Ciências, 28(1-2):10.

Stefanello MT (2020). Benefícios da tecnologia de aplicação em soja. Cultivar Grandes Culturas, 20(259):10-13. 